\title{
大出カレーザー応用の拡がり
}

\author{
宮永 憲明 \\ 大阪大学レーザーエネルギー学研究センター（テ565-0871 大阪府吹田市山田丘2-6）
}

\section{Extending Applications of High-Power Lasers}

\author{
Noriaki MIYANAGA \\ Institute of Laser Engineering, Osaka University, 2-6 Yamada-oka, Suita, Osaka 565-0871
}

(Received August 6, 2008)

\begin{abstract}
High-power laser is a typical multi-purpose technology that can be applicable to many fields including the basic science, the biomedical science and the metrology, inspection and fabrication in the material science and nanotechnology. This paper reviews high-power-laser produced radiation sources and applications of XUV rays, energetic ions and neutrons. In addition the relevant world trend of next generation high-power lasers is reviewed on E23, ELI and HiPER-Euro programs.
\end{abstract}

Key Words: High power lasers, Ultra short pulse, Laser-produced radiation source

1. はじめに

近年，光は研究室だけでなく多くの産業技術に至るま で浸透しつつあり，今日の科学技術・学術にとってなく てはならないものとなっている。このことは，言うまで もなく, 光(電磁波)には周波数をパラメーターとして非常 に広いスペクトル領域をカバーする普遍性があり，また 極めて狭帯域の単色光からその逆の極限である数 $100 \mathrm{THz}$ にも及ぶ超広带域まで制御可能であり,さらに単一光子 から超高強度にわたる広範囲の強度を選択できることか ら，多様なニーズに対応できる柔軟性を有しているから に他ならない. これに加えて, 光の電場・磁場の位相や 振幅分布を時間領域と空間領域で制御可能であること は, 多様な物質, 材料, 構造との特定の相互作用を抽 出・制御するための重要なツールとなる.つまり, 光科 学は本質的に分野融合的側面をもっているのである.

このような光を操る技術に立脚する光科学の重要性に ついては, 欧米では数年以上前から戦略的研究開発課題 として位置付けられてきた. 我が国でも, 科学技術・学 術審議会基本計画特別委員会から公開された「第3期科学 技術基本計画の重要施策 一知の大競争時代を先導する科 学技術戦略(平成17年4月8日)中間とりまとめ†1」には, 「光・光量子科学技術は非常に幅広い分野に対応する横断 的で重要な基盤であり，基礎研究から実用化まで一体的
な取り組みが必要」と謳われており, 推進すべき重点研究 テーマの1つとして,「高出力・短パルス, X線・テラヘル ツ光源開発・利用」が挙げられており，それらを具体化す る施策として，「最先端の光の創成を目指したネットワー ク研究拠点プログラム」が今年度から 10 年計画で実施され ることとなったげ

さて, 本特集号の主題である大出力レーザーについて は，その代表格は固体レーザーであり，Fig. 1に示すよう に核融合用のガラスレーザー，加工用のYAGレーザー， および高強度場科学研究などで用いられるフェムト秒 $\mathrm{Ti}$ ファイアレーザーなどがある。これらのレーザーでは, 個々の用途に応じてパルスエネルギー数 $10 \mathrm{~kJ}$, 平均パ ワー数 $\mathrm{kW}$, ピークパワー数 $100 \mathrm{TW}$ の性能を有するものが あるが, 高パルスエネルギー, 高平均パワー, 及び高 ピークパワーの3つを併せ持つレーザーは未だ存在しな い.しかし, そのような高繰り返し・高出力の超短パル スレーザーは近い将来に必ず実用化すると期待され, 光 科学へのインパクトには計り知れないものがある.

例えば，欧州が提案しているExtreme Light Infrastructure $(\mathrm{ELI}){ }^{\dagger 3}$ が目指しているように,「アト秒科学」,「レーザー 生成粒子線, 硬X線の医療応用」,「超短パルスコヒーレン トX線」,「核物理」,「プラズマ物理と相対論工学」,「材料 科学」,「高エネルギー物理や宇宙物理」など非常に広範囲 の科学技術 - 学術を推進するための, 新しく, かつ長期

\footnotetext{
${ }^{\dagger 1}$ URL: http://www.mext.go.jp/b_menu/shingi/gijyutu/gijyutu11/houkoku/05042301/021.htm(報告書の概要)

$\dagger^{2}$ URL: http://www.mext.go.jp/b_menu/houdou/20/07/08072808.htm

${ }^{\ddagger}$ URL: http://www.extreme-light-infrastructure.eu/
} 


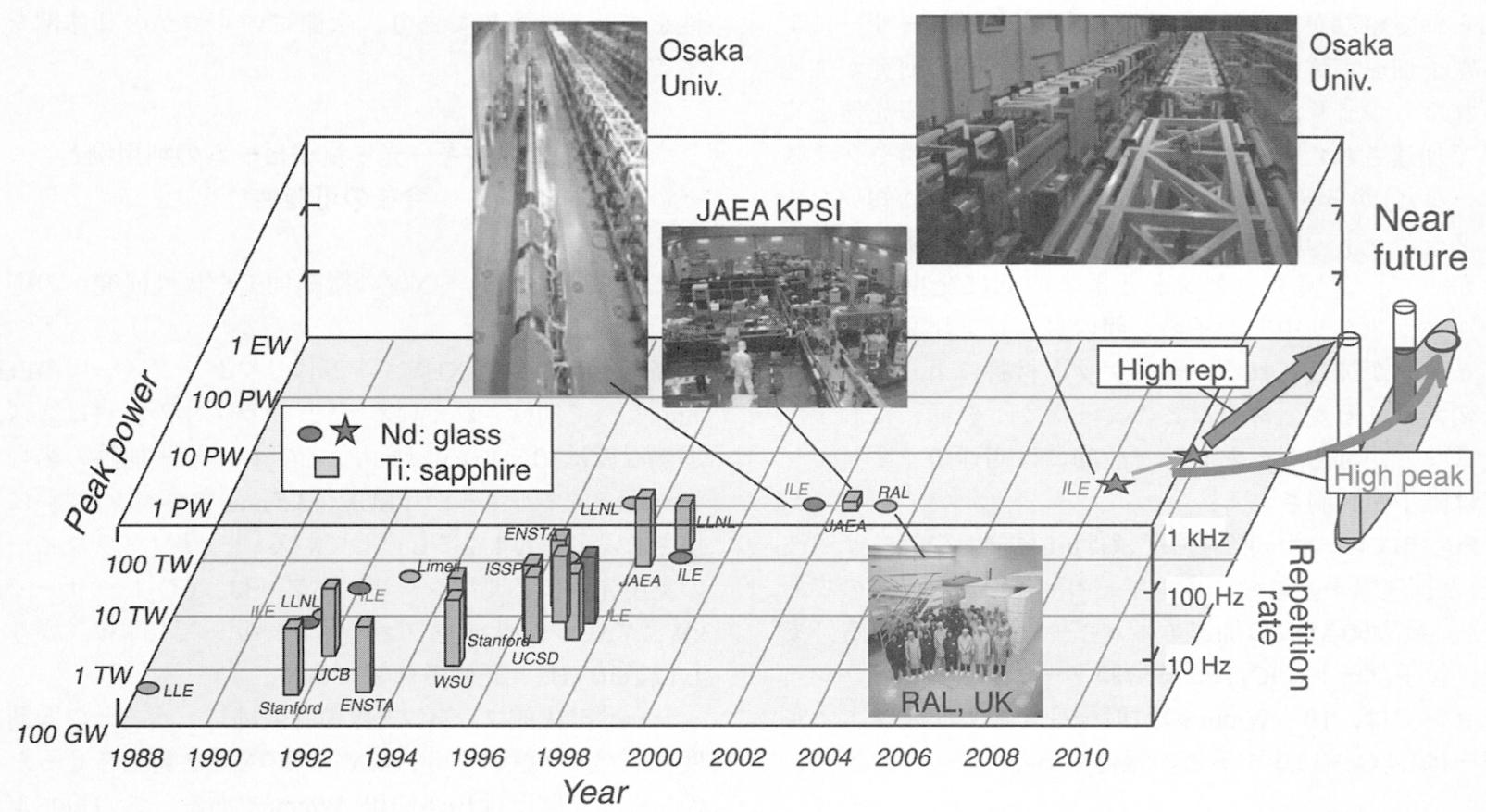

Fig. 1 Development of ultra-intense lasers in the world.

にわたって活用可能な基盤技術を提供することが期待さ れる。そして，汎用性の高い基盤技術を完成させるに は，ビーム品質のみならず光波の位相や振幅分布の時 間・空間制御を兼社備えた大出力レーザーの質的飛躍が 不可欠と考えられる.

本解説では，米国のE23や欧州のELIやHiPER-Euroの開 発動向について言及しつつ, 次世代大出力レーザー(高パ ルスエネルギー，高平均パワー，および高ピークパワー のレーザー)によって開拓される様々な新産業分野とそれ に必要なレーザー開発の目標について解説する。

\section{2.レーザー駆動の高エネルギー光・量子ビーム源}

\section{1 レーザープラズマX線源}

レーザー生成プラズマは強力な電磁波源であり，レー ザーの照射強度やターゲットの材料を変えることによ り, THz領域から, 赤外, 可視, 紫外, 真空紫外, 極端紫 外，軟X線，X線， $\gamma$ 線に至る幅広い周波数範囲で高輝 度・短パルスの電磁波を放出できる。また，X線レーザー や高次高調波のようなコヒーレント極短波長光源も実現 されている。このような高輝度性，短パルス性，点光 源，可干渉性などの特長は，時間分解分光による構造解 析や材料物性研究への応用，非破壊検査，微細加工，生 命科学，医療など，種々の分野で新しい応用が期待され ている.

2.2 超高強度レーザーとプラズマの相互作用

大出力レーザーにおいて物質との相互作用に大きな変 化を与えるのがピークパワーである。チャープパルス増 幅(Chirped Pulse Amplification，CPA)技術の進展とともに レーザーのピークパワーは飛躍的に増大し，テーブル トップサイズの装置でも TW $\left(10^{12} \mathrm{~W}\right)$ が容易に得られ，ま
た大型レーザー装置ではPW $\left(10^{15} \mathrm{~W}\right)$ に達している。この ような超高強度レーザーパルスの集光強度は $10^{18} \sim 10^{21}$

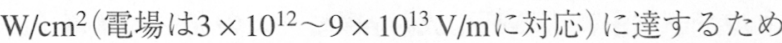
に，高温プラズマが発生し，高エネルギーのX線が放出さ れる。さらに，プラズマとの相互作用では非線形効果が 如実に現れるだけでなく，電子の運動は相対論的とな る。その結果として発生する高エネルギーの電子ビーム は，イオンを加速し，高Z物質との衝突によってガンマ線 や陽電子ビームを発生する。このようにして発生した高 エネルギーの光・量子ビームは原子核との相互作用を通 して核変換，核反応などを誘起することが可能で，超高 強度レーザーを基盤とする「レーザー核科学」ともいうべき 新しい学問分野が形成されつつある1-4).

\section{3 レーザー電子加速}

レーザー加速は，レーザー生成プラズマ中に励起され るプラズマ波の電場により電子を加速するものである が，最近はCPA超短パルス超高強度レーザーによる航跡場 加速が主流となっている ${ }^{5)}$. 加速勾配は数 $100 \mathrm{GV} / \mathrm{m}$ に達し ているので，加速エネルギーを向上させるには加速長 (レーザーの相互作用長)の増大が鍵となっていた。これに ついて近年，長尺の放電型ガスキャピラリー導波路の最 適化によって，40 TWレーザーパルスを $3.3 \mathrm{~cm}$ の長さにわ たってチャネリングし，平均エネルギー $1 \mathrm{GeV}$ ，エネル

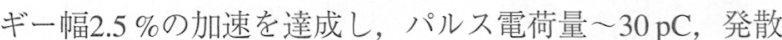
角 $1.6 \mathrm{mrad}$ の電子ビームを得ている6)。なお，今後の展開 としては，プラズマ生成の条件に左右されない方法とし て，超高強度レーザー光で生成する縦電場による直接加 速も期待される。

2.4 高エネルギーイオンビームの生成

レーザープラズマでのイオン加速は1980年代初頭から 
知られていたが, 最近の超短パルス高強度レーザーによ る電子加速実験の進展とともにイオン加速の研究が加速 された。つまり，超短パルスレーザーによって光速近く まで加速された電子は瞬時にターゲット（薄膜やクラス ターなど)から飛び出すが，レーザーパルス幅が短いため にターゲットの膨張が抑えられて電荷分離が生じる。し たがって，薄膜ターゲットと電子の間に発生する電場 や，クラスター中でのイオン間のクーロン反発力によっ てイオンが加速される.ターゲット材料によりイオン種 を変えられるが，薄膜などの夕ーゲット表面にはわずか な水などが付着しており，一般的には高速のイオンとし ては陽子が観測される。

Fig. 2はレーザー照射強度 $(\lambda は \mu \mathrm{m}$ 単位でのレーザー波 長) と加速陽子の最大エネルギーの関係を示したものであ り7)，最大 $60 \mathrm{MeV}$ の加速エネルギーが得られている。 た，粒子コード (PIC)による薄膜ターゲットのシミュレー ションでは, $10^{23} \mathrm{~W} / \mathrm{cm}^{2}$ の照射強度で最大イオンエネル ギーは $1.4 \mathrm{GeV} に$ 達するとの報告もある ${ }^{8)}$.

2.5 高エネルギー光・量子ビームとレーザー核科学 大出力レーザーにより生成されるプラズマからは, 上 に述べたように, 高エネルギーの電子やイオン, X線と いった強力な放射線源としての応用が可能となる．高工 ネルギー電子による制動放射 $\gamma$ 線ビームの発生と陽電子生 成, $\gamma$ 線による核変換, 高エネルギーイオンによる核反応 や核破砕をはじめとする核反応など，多くの実験結果が 報告されており，レーザー強度の増大とともにレーザー 核科学は大きく花開こうとしている。 また, 核反応を利 用した短寿命核種の製造とPET (Positron Emission Tomography)への応用, 高エネルギーイオンの直接利用や中性 子(ホウ素による中性子補獲)による癌治療, 陽子, 中性 子， $\gamma$ 線を利用したラジオグラフィ， $\gamma$ 線による核変換を 利用した高レベル放射性廃棄物の処理など，具体的な応 用も数多く提案されている. Fig. 3はそれらの応用の可能

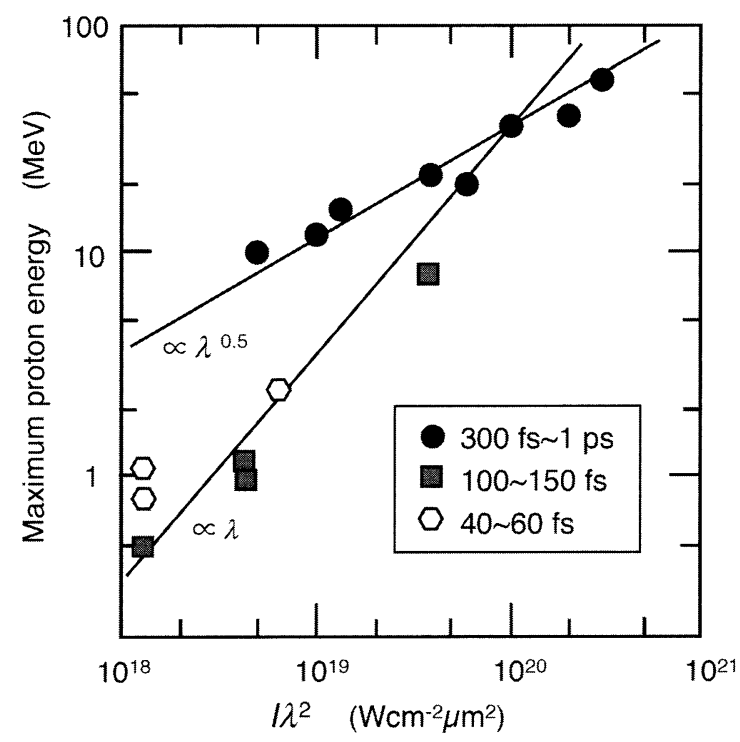

Fig. 2 Maximum proton energy depending on laser irradiation intensity.
性をまとめたものであり，次節にいくつかの具体例を示 すことにする.

\section{3. 高エネルギー光・量子ビームの利用例と 今後の可能性}

\section{1 高輝度 $X U V \sim X$ 線の微細加工や物性研究への応 用}

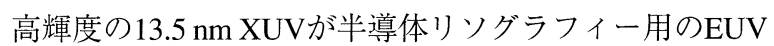
光源として期待されている9-11). プラズマの材料はスズ, 加熱温度は30〜 $40 \mathrm{eVであり,} \mathrm{CO}_{2}$ レーザー加熱の場合の レーザーエネルギーから EUV $(13.5 \mathrm{~nm}, 2 \%$ バンド幅 $)$ に変 換される効率は $4 \%$ に達している12). リソグラフィー用

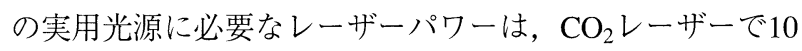
$\mathrm{kW}, \mathrm{YAG} レ$ ザーやファイバレーザーで $15 \mathrm{~kW}$, 繰り返 しは数10 kHzと評価されている.

レーザー生成プラズマX線の特徴はレーザーとの同期精 度と短パルス性にあり, $\mathrm{keV}$ 領域のX線を発生させるため

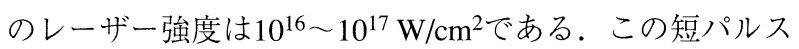
X線は, ピコ秒分解能のポンプ・プローブ計測に活用され ており, 計測の例としては半導体や部分電離プラズマの 時間分解軟X線吸収分光やレーザー励起された半導体の結 晶格子のX線回折によるダイナミクス計測がある13). 今 後, 非平衡, 平衡状態間などの構造変化といった分子動 力学に関連した計測が進展するものと期待される.

一方，レーザー生成プラズマを増幅媒質として利用す るX線レーザーの開発には長い歴史がある。最近, 波長数 $10 \mathrm{~nm}$ 領域で数psのパルス幅や単色性 $\left(\Delta \lambda / \lambda \sim 10^{-4}\right)$ を利用し て, XUV領域のスペックル分光, 固体表面のアブレー ション，物質の内核電離に伴う物性研究などが始まって いる ${ }^{14)}$. さらに, XUV領域のコヒーレント光源として高 次高調波 ${ }^{15,16)}$ があり，その特長である光波位相の精密制御 や超短パルス性を活かしてアト秒領域の物理やXUV非線 形光学という新しい研究分野が拓かれようとしてい

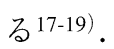

$3.2 \mathrm{X}$ 線の医療応用と $\gamma$ 線による放射性廃棄物処理 X線源の単色性や光源サイズを改善することによって, 医療用画像計測や治療技術の向上が期待できる.X線透過 画像において，単に吸収分布のみならず位相変化を捉え ることによって, 細胞レベルや生物組織の詳細な診断が 可能となる。これは位相コントラストイメージングとよ ばれる手法であり，フェムト秒レーザー照射 $\mathrm{Mo}$ の $\mathrm{K} \alpha$ 線 $(17 \mathrm{keV})$ を用いた昆虫の画像計測が試されている20).X線 領域の高輝度コヒーレント光源が実現されれば, さらに 沉用画像計測として実用化に近づくと期待される.

準単色X線の医療応用として, ヨウ素イメージングや オージェカスケード治療とよばれるガン組織の選択治療 がある。ヨウ素イメージングはガン組織に集まり易い夕 ンパク質分子の一部をヨウ素化合物で置き換えることに よって，ガン組織の画像計測の画質向上を目指す方法で ある21).このヨウ素イメージングはK核電子によるX線吸 収 (内核電離)を利用するものであり, X線の光子エネル 


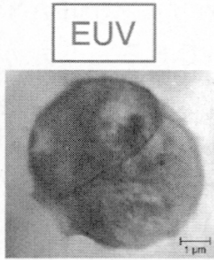

EUV microscope (CXO, LBL)

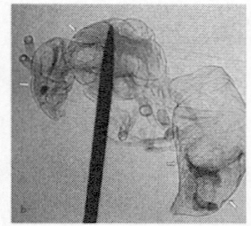

Phase contrast imaging (R. Toth, et al.)

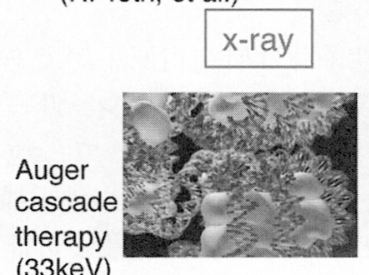

(33keV)
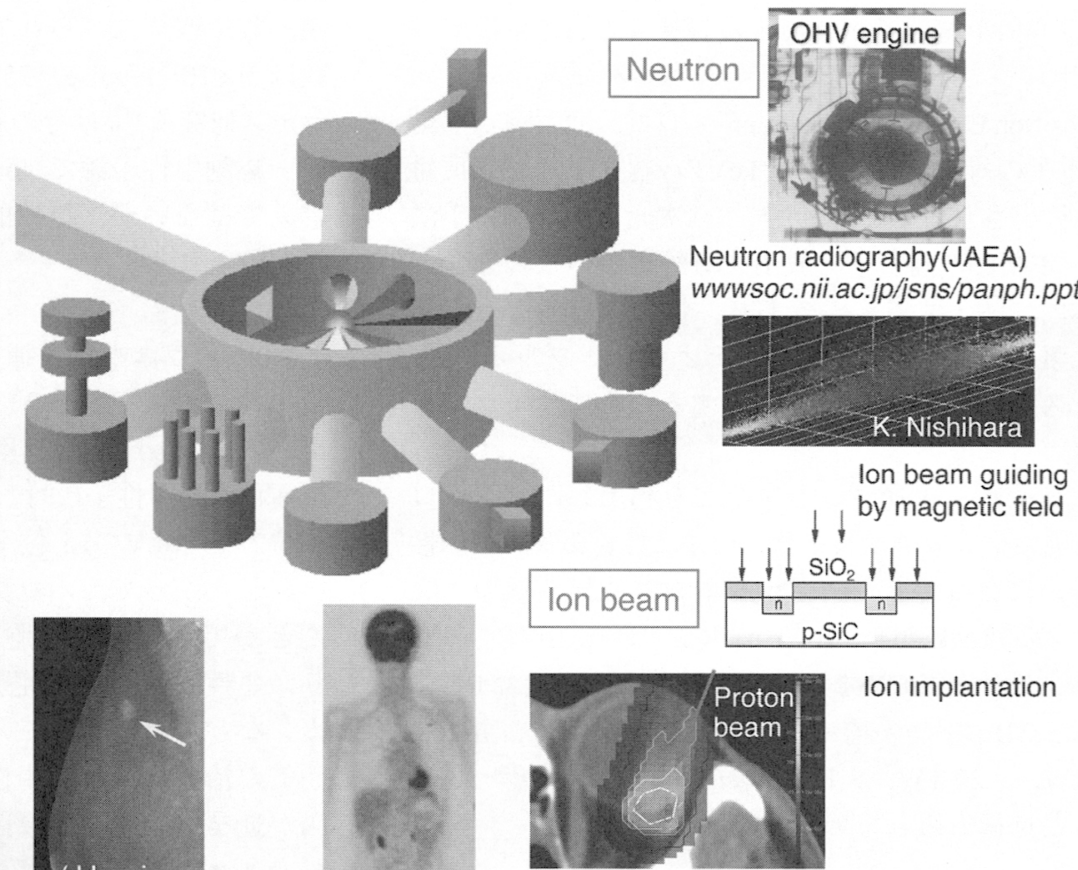

Ion beam therapy

(human eye)

JST CREST/

JAEA/HIMBMC

Fig. 3 Possible applications of next generation high-power lasers as a muti-purpose technology.

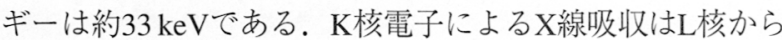
$\mathrm{K}$ 核及びM核からL核へカスケード的に生じるオージェ遷 移を引き起こし，これらのオージェ遷移に伴って軟X線が 放出される。したがって，オージェカスケード過程をガ ン治療 (ガン細胞DNAの切断)に活用すると，K核電離に伴 う過程とカスケード過程が狭い領域で生じるために，治 療効果の向上が期待される22)。なお，このカスケード オージェ過程はフェムト秒の時間スケールで起こるた め，フェムト秒〜アト秒パルス幅のX線光源が実用化され れば, 半導体の高励起状態の緩和過程の研究にも利用で きると考えられる。

現在のところ，このような準単色X線の発生方法として は, 加速器における電子と高輝度レーザー光との衝突に よるコンプトン散乱が提案されている。さらに，レー ザーコンプトン散乱を $\gamma$ 線領域にまで広げ，原子核の巨大 共鳴エネルギーと一致させて，放射性廃棄物の消滅処理 に利用しようという試みもある23)。将来的には，高繰り 返し・高強度レーザーによる特性X線の発生や相対論領域 までに加速された電子による $\gamma$ 線 (制動放射) ビームの利用 も可能と考えられる。

\section{3 高エネルギーイオンビームによるガン治療}

粒子線治療用のイオンビームとしては陽子線と重粒子 線(炭素線)が用いられており，荷電粒子のエネルギー減衰 におけるブラッグピークによって， $\gamma$ 線に比べて患部への 集中的エネルギー投入が可能であるという特長がある.
陽子線は，国立がんセンター，静岡がんセンター，筑波 大，若狭湾エネルギー研究センターに設置されており， 名古屋市，福井県，宮城県で新たな施設が造られようと している。これに対して炭素線は，放射線医学総合研究 所，千葉市重粒子線医科学センター病院で稼働してお り，群馬大でも建設中である。また，陽子線と炭素線の 両者が設置されているのが兵庫県立粒子線治療センター である。治験症例は各機関のホームページで確認できる が，多様なガンに適用可能なことと手術が困難な症例で も威力を発揮するのが特長であるけ4。ただし，治療費は平 均的に 300 万円程度と高く，治療患者数も十分とは言えな w.

この粒子線治療を広く普及させるには，加速器及び付 帯設備としての放射線遮蔽のコストを大幅に削減する必 要があり，レーザーを用いた粒子線加速器の医療応用を 目指した研究がスタートしている。日本原子力研究開発 機構では光医療産業バレー24,75)の開発を進めており，その 第一ステップとして50〜80 MeV陽子線を開発し，そのス ポットスキャン方式による体表面近傍の病巣治療機の開 発を掲げている。最終的には，深部ガンにも対応するた めに200 MeV級の装置開発に向かうとしている。また，陽 子照射部で発生する核変換を積極的に活用して，自己放 射化PETによる照射線量のリアルタイムのトモグラフィッ クなモニターが可能と考えられている.

†4 例えば，兵庫県立粒子線治療センターでは，URL: http://www.hibmc.shingu.hyogo.jp/

${ }^{75}$ URL: http://wwwapr.kansai.jaea.go.jp/pmrc/ 
3.4 高エネルギーイオンによる核変換とPETへの応 用

PET(Positron Emission Tomography) とは，ポジトロン(陽 電子) と電子の対消滅に伴う $511 \mathrm{keV}$ の $\gamma$ 線光子対が正反対 の方向に放出されることを利用した3次元画像計測の手法

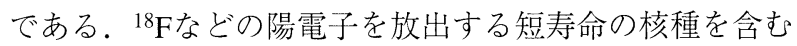
試薬を体内に注入するものであり，癌細胞に多く取り込 まれる試薬の例としてはFDG，2-デオキシ-2-フルオロ-Dグルコースなどがあり， ${ }^{18} \mathrm{~F} て ゙$ 標識するためにサイクロト ロンが用いられている。

近年，レーザー駆動プロトンなどを利用したポジトロ ン放出核種の生成実験が行われ，PETに必要なレーザー性 能が明らかになってきた ${ }^{25)}$. ポジトロン放出核種の生成 に利用できる核反応は， ${ }^{11} \mathrm{~B}(\mathrm{p}, \mathrm{n}){ }^{11} \mathrm{C},{ }^{13} \mathrm{C}(\mathrm{p}, \mathrm{n}){ }^{13} \mathrm{~N},{ }^{16} \mathrm{O}$ $(\mathrm{p}, \alpha){ }^{13} \mathrm{~N},{ }^{18} \mathrm{O}(\mathrm{p}, \mathrm{n}){ }^{18} \mathrm{~F}$ などであり, PETに必要な $1 \mathrm{Gbq}$ の ${ }^{11} \mathrm{C} ， 0.5 \mathrm{GBq}$ の ${ }^{18} \mathrm{~F}$ 標識核種を生成するには，1J，1 $\mathrm{kHz}, 1 \mathrm{~kW},>20 \mathrm{TW},>10^{19} \mathrm{~W} / \mathrm{cm}^{2}$ 程度のレーザーが必 要であると見積もられている。

\section{5 レーザー駆動中性子源とその応用の可能性}

レーザー核融合では，1980年代に $10^{13}$ 個/ショットのDT (14 MeV) 中性子が得られている. 近年の小型テーブル トップ高強度レーザー技術の進展とともに中性子発生実 験が行われ26-29)，レーザー駆動中性子源としての期待が高 まっている。レーザー駆動中性子源には，熱核融合反 応, レーザー加速イオンによるビーム核融合, 及び核破 砕中性子が考えられる.

Perkinsらは，核融合炉材料の研究開発用に，DT核融合 を利用したレーザー駆動中性子源を提案している30). 一 方, Zagarらは, レーザーによる陽子加速と $\mathrm{Zn}(p, x n) \mathrm{Ga}$ 反 応による中性子発生実験を基に，次のような評価をして いる31)。 ${ }^{7} \mathrm{Li}(p, n)^{7} \mathrm{Be}$ と $\mathrm{Zn}(p, x n) \mathrm{Ga}$ 反応に扮ける陽子か ら中性子への変換効率としては, 前者では $10^{-3}$ 程度 (陽子 エネルギー5〜 $6 \mathrm{MeV}$ ), 後者では $10^{-3} \sim 10^{-2}$ (陽子エネル ギー20〜 $40 \mathrm{MeV}$ )が期待でき， $200 \mathrm{~J}, 150 \mathrm{fs}, 10^{21} \mathrm{~W} / \mathrm{cm}^{2}$ のレーザーにより $(5 \sim 10) \times 10^{10} \mathrm{n} /$ pulseが得られると予測 している.

中性子の応用については，これまで原子炉中性子を用 いて, 磁性体の相転移やスピンダイナミクスなどの物性 科学, タンパク質の水素・水和構造解析や植物根成長の 観察などの生物科学, ポリマーなどの高分子科学, 構造 材料内の残留応力評価やエンジン, 燃料電池の内部構造 の可視化などの産業利用などが行われてきた。このよう に中性子の応用は極めて多岐にわたっており，それを受 けてJ-PARCでは, 軽元素, 特に水素の識別能力, 中性子 回折による生体物質の原子構造解析, ナノテクノロジー や超伝導材料科学のための磁気構造解析, 鉄鋼材料の水 素脆性や疲労破壊に関する非破壊検査などが主な研究課
題として取り上げられている 数は $5 \times 10^{15} \mathrm{n} /$ pulse, $25 \mathrm{~Hz}$ であり, 米国LANSCE(ロスア

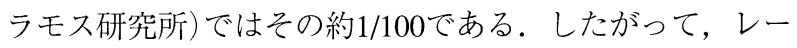
ザー駆動中性子源で加速器中性子源を置き換えることは 容易ではないが, 比較的小規模の研究設備としての活用 が期待される。

\section{6 ホウ素中性子捕捉ガン治療}

中性子の医療応用の1つとしてホウ素による中性子捕捉 反応 $\left({ }^{10} \mathrm{~B}(\mathrm{n}, \alpha)^{7} \mathrm{Li}\right)$ を利用したガン治療がある ${ }^{\dagger 7}$. この反応 断面積は熱中性子に対して〜3800 b と極めて大きく, 生成 する2 3 MeVのLi 粒子と $\alpha$ 粒子の飛程は5～10 $\mu \mathrm{m}$ と短 い.したがって，ホウ素化合物をガン組織に集中させる ことができれば，細胞レベルでのガン治療が可能とな り, 悪性脳腫瘍, 悪性黒色腫, 頭䅡部ガン, 肺ガン, 肝 ガンなどに適用されている.

この治療における中性子源は研究用原子炉であり, 臨 床が進まないことの原因となっている。レーザーで加速 したイオンビームを活用することによって, 粒子線治 療，PET及び核破砕中性子源によるホウ素中性子捕捉ガン 治療を一括して行うことができる医療施設が可能になる と考えられる.

\section{4. 関連するレーザー開発研究}

\subsection{X線自由電子レーザー}

X線自由電子レーザー (XFEL) は2010年前後の完成を目 指して，日米欧で激しい競争が行われている。我が国の XFELは国家基幹技術の1つとして, SPring-8のサイトに建 設中であり ${ }^{\dagger 8}$, その基本性能は, 電子ビームエネルギー8 $\mathrm{GeV}$, 繰り返し $60 \mathrm{~Hz}$, X線波長 $>0.06 \mathrm{~nm}$, パルス幅 $<100$ fs, ピーク輝度 $10^{33}$ photons $/ \mathrm{s} / \mathrm{mm}^{2} / \mathrm{mrad}^{2} / 0.1 \% \mathrm{BW}$ となって いる†9. 一方米国では, スタンフォード線形加速器セン 夕ー(SLAC)のLCLS (Linac Coherent Light Source, 波長0.15 $\mathrm{nm})$ が2009年の完成を目指している。これに対して欧州で は，ハンブルグのドイツ電子シンクロトロン研究所 (DESY)を中心として進められているヨーロッパX線自由 電子レーザー (Euro XFEL, 波長 $0.085 \mathrm{~nm}$ )を2013年に完成 させる計画である。

これらのXFELと比較して, レーザー高次高調波は短波 長性とピーク輝度では劣るものの, 超短パルス性, 高い 繰り返し周波数，極めて良好なコヒーレンス性及びレー ザー駆動の他の電磁波源や量子ビームとの同期性能な ど，XFELにはない特長がある。したがって，XFELの利 用研究で必要とされる技術をレーザー高次高調波を用い て開発可能であるだけでなく, 将来的にも相補的に利用 されることが予想される。

\footnotetext{
${ }^{76}$ URL: http://j-parc.jp

${ }^{7} 7$ URL: http://wwwa.jnc.ne.jp/ffid0000/explanation.html

$\div 8$ URL: http://www.riken.jp/XFEL/jpn/whatis/index.html

${ }^{\circ 9}$ URL: http://www.harima.riken.go.jp/data/XFELjpn.pdf
} 
4.2 Mercuryの増力と $10 \mathrm{~Hz}$ ペタワット計画(米国) 半導体レーザー (LD) 励起, パルス増幅の大出力レー ザーは日米欧で開発が進められているが，最高出力を出 しているのが米国ローレンスリバモア研究所のMercury レーザーである.Yb:S-FAP結晶の多重パルスシステムで

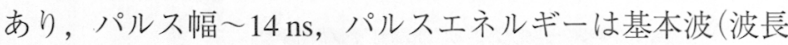
$1047 \mathrm{~nm}$ ) で65 J/pulse，2倍高調波で32 J/pulseを $10 \mathrm{~Hz}$ で達 成している。同研究所では，このMercuryを活用して $10 \mathrm{~Hz}$ 動作する PWレーザー(E23プロジェクト)の開発に着手し た。

E23 (Fig. 4参照) 32)では, Mercuryの所期の目標である100 J/pulseを達成した後，70 Jの2倍高調波に変換し，これを 励起光としてTi:サファイア4パスCPA増幅器を駆動し, 16 fsの圧縮パルスで $15 \mathrm{~J} / \mathrm{pulse}$ の出力達成を見込んでいる。ま た，レーザー集光強度の目標を $10^{23} \mathrm{~W} / \mathrm{cm}^{2}$ に設定して， プロトンの相対論領域に肉薄しようとする野心的な計画 であるが，上記のパルス幅の達成とビーム品質の向上が 鍵となっている。

\subsection{ELI計画(欧州)}

ELIは欧州で計画中のレーザー装置であり，Fig. 5に示す ようなシステム構成が検討されているけ3,†10。フェムト秒パ ルスでサブエキサワット $\left(\mathrm{EW}=10^{18} \mathrm{~W}\right)$ のピークパワーを 実現し, 高強度場光科学・相対論光科学, アト秒レー ザー科学，レーザー核科学などの開拓を目指している.

ELIのフロントエンドは, Fig. 6に示すようなものであ る. 大出力レーザーの基本技術は，ドイツイエナ大学の Polaris (LD励起のYb: ガラスレーザー) やフランスLULI研 究所のLucia(LD励起アクティブミラー型のYb: YAGレー ザー)であり，フェムト秒レーザーシステムとしては，ド イツMPQ研究所で開発中の $10 \mathrm{~Hz}$ システムの延長線上にあ り，Yb: YAGレーザーを励起源としたnon-collinear OPCPA (NOPA)が最終増幅段として採用される予定である。パル ス幅 $<5 \mathrm{fs}$ ，パルスエネルギー>3 J, 繰り返し周波数 10 $\sim 1000 \mathrm{~Hz}$ ，ピークパワー>500 TW，中心波長 $800 \mathrm{~nm}$ あり，集光強度 $>10^{22} \mathrm{~W} / \mathrm{cm}^{2}$ を目指すとしている。

なお, Fig. 5のパワー増幅器の励起源は, フラッシュラ ンプ励起Nd:ガラスレーザーあるいはLD励起の結晶媒質で あり，繰り返し周波数はこれに依存して $0.1 \sim 1 \mathrm{~Hz}$ の範囲

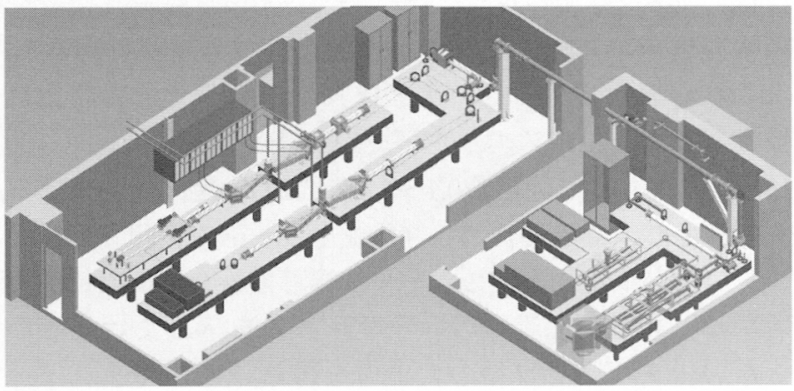

Fig. 4 E23 program based on Ti:sapphire fs laser pumped by Mercury Yb:S-FAP laser. ${ }^{32)}$
と想定されている。フェムト秒増幅器は初期設計では Ti: サファイアであるが，OPCPAの可能性も検討されてい る。最終的に10本のビームによってサブEWを目指すとし ており，コヒーレントビーム結合技術の開発が不可欠と なっている。

\subsection{HiPER-Euro計画 (欧州)}

欧州では，フランスのLIL（核融合用レーザーLMJのプ ロトタイプとしてボルドーに完成済みのナノ秒レーザー) 及びそのサイトに現在建設中のPWレーザーPETAL (PETawatt Aquitaine Laser ${ }^{\dagger 11}$ )の技術を基盤として，日米の 関連研究所とも連携して高速点火核融合研究用のレー ザーであるHiPER (High Power Experimental Research Facility ${ }^{\dagger 12}$ )計画 (Fig. 7参照)が提案されている。 $200 \mathrm{~kJ}$ の爆 縮用レーザー (40ビーム， $5 \mathrm{~ns})$ と $70 \mathrm{~kJ}$ の点火用レーザー (1 ビームバンドル，10 ps）を2015 年に完成させることを目指 している。さらに核融合以外の波及効果を目指して, OPCPAを用いた $30 \mathrm{fs} ， 150 \mathrm{PW}$ よび，15 fs，2.5 EWの超 短パルスのオプションが検討されている。将来の炉用 レーザー開発を目指して1ビームをLD励起固体レーザー (DPSSL) システムとする構想も検討されている。このよ うな $10 \mathrm{~kJ}$ 級のDPSSLに関しては，HiPER計画書 (HiPERTDR.pdf，上記のホームページから入手可能)の付 録として, HALNA(日本), Mercury(米国), Polaris(ドイ ツ), Lucia(フランス)の比較も含めて概要がまとめられて いる.

\section{5. 次世代大出カレーザーの開発について}

Fig. 8に，10Hz 以上の繰り返し性能を有する世界の高 ピークパワー超短パルスレーザー開発の状況を示す．10 fs

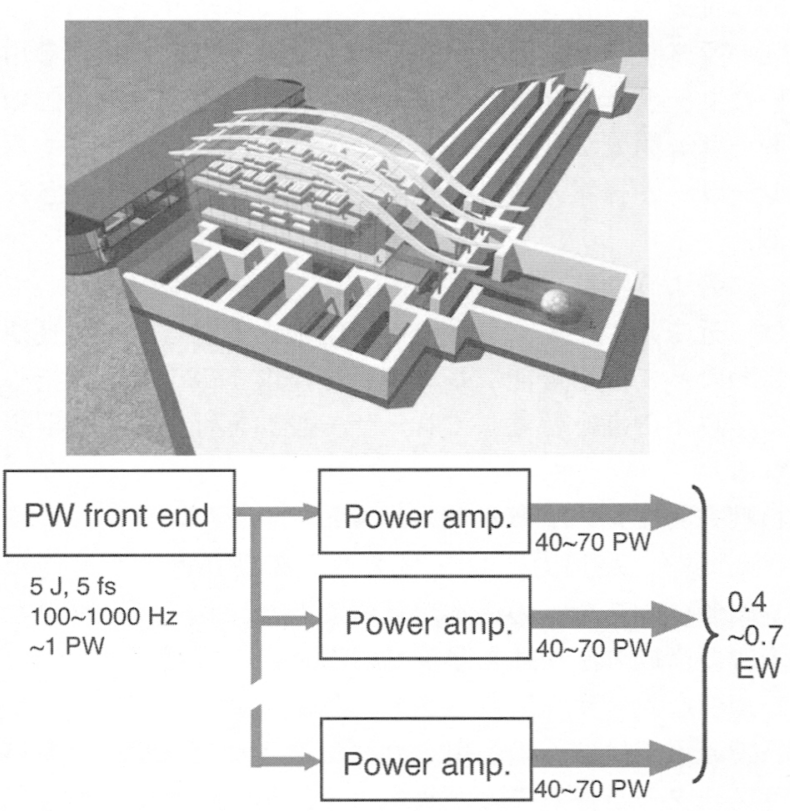

Fig. 5 System layout and schematic diagram of ELI. ${ }^{\dagger 10}$

\footnotetext{
${ }^{\dagger 10}$ URL: http://www.extreme-light-infrastructure.eu/pictures/ELI-scientific-case-id17.pdf ${ }^{\dagger 11}$ URL: http://petal.aquitaine.fr/
} 


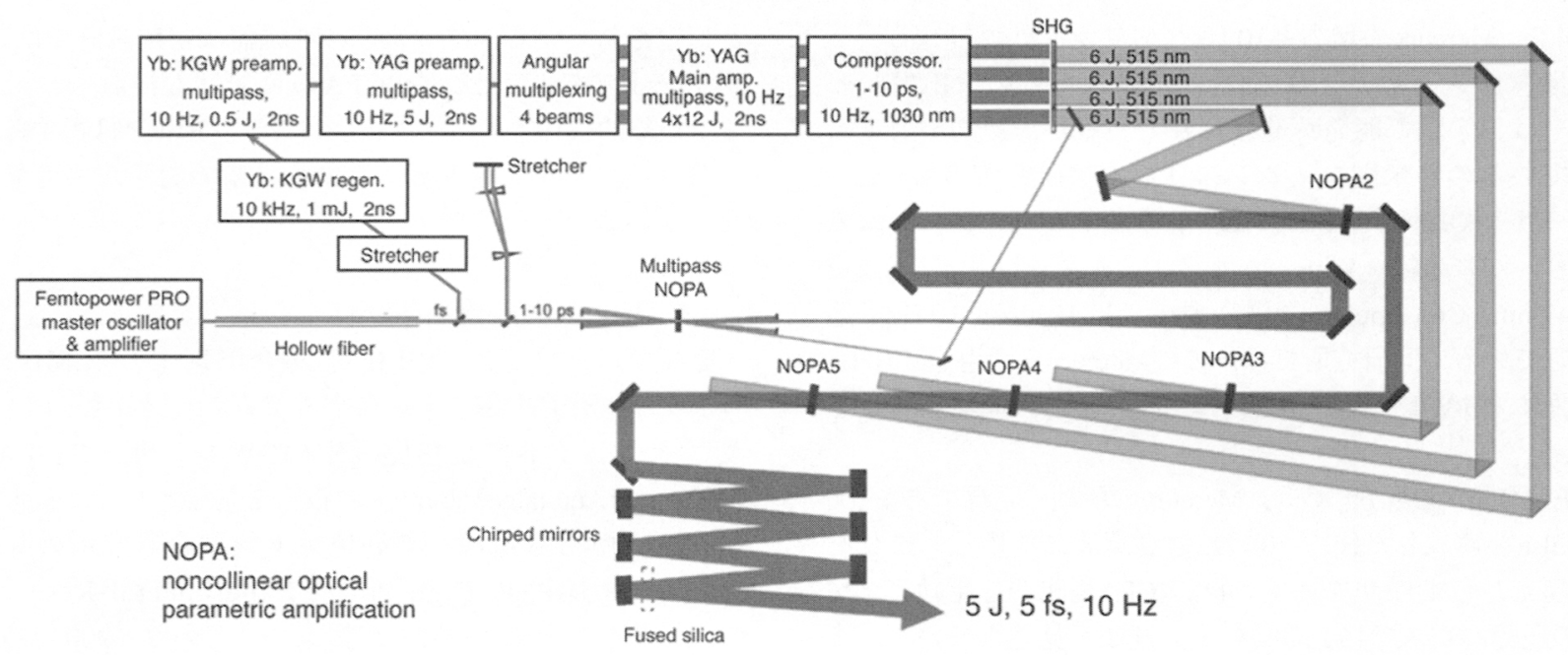

Fig. 6 Schematic layout of the ELI 10-Hz front-end. ${ }^{\dagger 10}$



Fig. 7 Schematic illustration of HiPER-Euro facility. ${ }^{\dagger 12}$

以下のパルス幅では, 高繰り返しで PW 出力を目指すた めに従来のTi:サファイアを基盤とするレーザー技術から 光パラメトリックチャープパルス増幅 (OPCPA) 技術を用 いたレーザー開発へとシフトしつつある。今後, 各国の レーザー開発が本格化するにつれてOPCPA を基盤とする レーザーが提案, 設計, 実現されていくものと予測され る.

このような観点から，大出力レーザーの開発において は, 近未来の産業, 科学技術·学術を較引し, かつ長期 にわたって活用可能な基盤技術を提供することを目指し て，以下の点を留意してレーザー設計を行うことが望ま れる。

1)魅力的なレーザーのコンセプト

高効率, 高出力, コンパクト, 高繰り返しが可能な レーザーシステムの提案が重要であり,レーザー材料と 増幅器構成方法が鍵を握っている.

2)適切なレーザー出力パラメーター

できるだけ多くの応用をカバーできるレーザー出力パ ラメーターを探ることが望まれる。したがって, 単なる パルスエネルギーの大きさだけでなくピーク強度や繰り

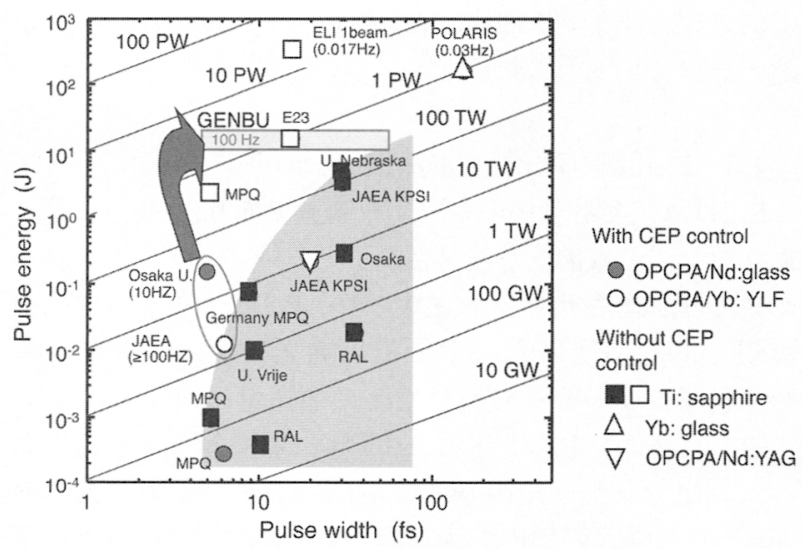

Fig. 8 World trend of ultra-intense lasers with high repetition rate.

返しも重要であり, 光-光変換による広带域増幅やパルス 圧縮などの先端技術も取り入れて，1つのシステムで高パ ルスエネルギー, 高ピークを併せ持つ高繰り返し・高平 均出力レーザーを設計することが妥当である.

3) 設計の拡張性, 発展性

将来のさらなる大出力化のために適切なコストでのモ ジュール開発を目指す必要があり, その開発を通じて主 要技術の実験的検証が可能であることが望まれる。さら には，異なった出力パラメーターに対しても設計指針や 増幅方式のコンセプトが活用できることも重要である。

これらを総合すると, 次世代大出力レーザーの開発目 標としては，パルスエネルギー $1 \mathrm{~kJ}$ (モジュールとして 100 J程度), 繰り返し周波数 $0.1 \sim 1 \mathrm{kHz}$ のLD励起固体レーザー を基盤とし, その動作パルス幅を数 $\mathrm{ns} \sim \mathrm{ps}$ の範囲で可変と することが望まれる。このパルス幅可変性をCPAで付加す るには，比較的広帯域のレーザー媒質を選ばなければな らない，また，ピコ秒の大出力を得ることができれば， OPCPAによるフェムト秒高繰り返しPWレーザーの開発に も有利である。本特集号では，このような観点に基づ

${ }^{\dagger 12}$ URL: http://www.hiper-laser.org/index.asp

阪大レーザー研のHIPER (High Intensity Plasma Experimental Research) と区別するためにHiPER-Euroとよぶ場合もある. 
き, $\mathrm{Yb}$ 系セラミック材料, ピコ秒大出力レーザー, ピコ 秒レーザー励起OPCPAレーザーを取り上げている。

\section{6. まとめ}

我が国の大出力レーザー関連の技術としてはセラミッ クレーザー材料，石英などの高品質光学材料，それらの 研磨・コーティング技術, 高出力半導体レーザー, レー ザー装置のシステム構築・制御技術など個々には高い技 術が存在する。また，モノサイクルに近づくフェムト秒 超短パルス技術や搬送波包絡線位相制御など，先端的光 波制御に関するトップレベルの研究も精力的に進められ ている．真に大出力レーザーのイノベーションを引き起 こすには，これらの国内技術を統合し，ナノテク・材料 科学, ライフサイエンス・医療, 基礎科学などの研究者 も参加して, 出口を明確にしたインフラ整備が強く望ま れる.

\section{謝 辞}

本解説は，IFEフォーラム/レーザー核融合技術振興会・ 大出力レーザー開発委員会の活動をもとにまとめたもの である．同委員会委員及び協力者の名簿(敬称略)を記し， これらの多くの方々に感謝の意を表する.

大出力レーザー開発委員会委員

委員長：井澤 靖和 (大阪大学)

委員：植田 憲一(電気通信大学), 江畑 恵司 (住友電気工 業(株)，，大和田野芳郎((独)産業技術総合研究所)，金邊 忠 (福井大学)，川嶋利幸 (浜松ホトニクス(株))，黒澤宏 ((独) 科学技術振興機構)，阪部 周二 (京都大学)，鈴木 良和 (レーザーフロントテクノロジーズ(株))，惣万芳人 (三菱重工業(株)), 高橋勉 ((株) ユニタック), 田中 和彦 (日新電機 (株)), 中野 人志, 吉田 実 (近畿大学), 西前 順一(三菱電機(株)), 初田 洋司雄 ((財)航空宇宙技術振興 財団), 藤田 和久 (光産業創成大学院大学), 藤田 雅之 （(財）レーザー技術総合研究所)，藤ノ木 朗 (信越石英 (株)，望月 孝晏 (兵庫県立大学), 山川考一((独)日本原 子力研究開発機構)，山村 史彦 (昭和オプトロニクス
(株)), 柳谷 高公 (神島化学工業(株)), 鷲尾 邦彦((有)パ ラダイムレーザーリサーチ)，猿倉 信彦，實野 孝久， 中塚 正大，河仲準二，椿本 孝治 (大阪大学)

協力者 (講演者) : 北川 米喜 (光産業創成大学院大学), 吉田 英次 (大阪大学)，ウィグナラージャ・シバクマラン (大成建設 (株) ), 今崎一夫 ( 財) レーザー技術総合研究 所), 石出 孝 (三菱重工業 (株) ), 中野秀俊 (日本電信電話 (株) ), 大道 博行 ((独) 日本原子力研究開発機構), 中島 康裕 (昭和オプトロニクス (株)), 佐野 雄二((株) 東芝), 菅 博文，宮島 博文 (浜松ホトニクス(株))

\section{参考文献}

1）阪部 周二，他：原子力学会誌 43 (2001) 996

2) A. Andreev, et al.: Quantum Electron. 31 (2001) 941.

3) T. Tajima and G. Mourou: Phys. Rev. Spec. Topics Accelerators Beams 5 (2002) 031301.

4) K. Ledingham, et al.: Science 300 (2003) 1107.

5) 北川 米喜：レーザー研究 34 (2006) 103

6) W. P. Leemans, et al:: Nature Phys. 2 (2006) 696.

7) M. Borghesi, et al.: Fusion Sci. Technol. 49 (2006) 412.

8) T. Esirkepov, et al.: Phys. Rev. Lett. 92 (2004) 175003.

9）レーザー研究 32, No.12 (2004).

10）宮永 憲明：O plus E 28 (2006) 1256.

11）有我 達也, 遠藤 彰：O plus E 28 （2006） 1263.

12) S. Fujioka, et al.: Appl. Phys. Lett., to be published.

13）レーザー研究 30, No.9 (2002).

14）プラズマ・核融合学会誌 84, No.7 (2008).

15) R. Bartels, et al.: Science 297 (2002) 376.

16) A. Paul, et al.: Nature 421 (2003) 51.

17）レーザー研究 36, No.1 (2008).

18）渡部 俊太郎, 足立 俊輔：応用物理 76 (2007) 115.

19）鍋川 康夫，緑川克美：応用物理 76 (2007) 133.

20) R. Toth, et al.: Rev. Sci. Instrum. 76 (2005) 083701.

21) J. Lewin, et al.: Radiology 229 (2003) 261.

22) J. Pignol, et al.: Int. J. Radiation Oncology Biol. Pys. 55 (2003) 1082.

23）今崎一夫，他：レーザー研究 27 (1999) 14

24) 河西俊一, 他：レーザー研究 36 (2008) 440.

25) K. Ledingham, et al.: J. Phys. D: Appl. Phys. 37 (2004) 2341.

26) G. Prezler, et al.: Phys. Rev. E 58 (1998) 1165.

27) T. Ditmire, et al.: Phys. Plasmas 7 (2000) 1993.

28) K. Lancaster, et al:: Phys. Plasmas 11 (2004) 3404.

29) J. Yang, et al.: J. Appl. Phys. 96 (2004) 6912.

30) L. J. Perkins, et al.: Nuclear Fusion 40 (2000) 1.

31) T. Zagar, et al.: in Laser and Nuclei (Springer, 2006).

32) A. Bayramian, et al.: private communication, 4-th International Workshop on High-Energy-Class DPSSL, Osaka, Sept. 17-19, 2007. 